\title{
USE OF BENZOTHIADIAZOLE (BTH) FOR INDUCING SYSTEMIC RESISTANCE IN COTTON SEEDLINGS AGAINST SOME SOIL-BORNE PATHOGENIC FUNGI El-Samawaty, A.M.A.* and A. A. Galal ${ }^{* *}$ \\ * Cotton Pathol. Lab., Plant Pathol. Res. Inst., Agric. Res. Centre, Giza, Egypt. \\ ${ }^{* *}$ Department of Plant Pathology, Faculty of Agriculture, Minia Univ., Minia, Egypt.
}

\begin{abstract}
The resistance elicitor Benzothiadiazole (BTH) has no significant inhibitory effects on seed germination of cotton cultivars Giza 86 and Giza 90 or on mycelial growth of the tested fungi, i.e. Fusarium solani, F. oxysporum, F. moniliforme, Sclerotium rolfsii, Macrophomina phaseolina, Pythium sp. and Rhizoctonia solani. BTH seed treatment (seed soaking) resulted in resistant cotton plants against infection by all pathogenic fungi tested. Efficiency of BTH to induce resistance in cotton seedlings varied with BTH concentration and fungi tested. Increasing BTH concentration enhanced resistance capacity of cotton cultivars. In addition. When the concentration was increased to $100 \mathrm{ppm}$, BTH significantly increased plant height from 8.36 to $26.07 \%$ and from 8.93 to $28.82 \%$ for cvs. Giza 86 and Giza 90 , respectively. Also, it increased dry weight from 2.87 to $53.26 \%$ and from 9.85 to $31.16 \%$ for cvs. Giza 86 and Giza 90, respectively. The highest efficiency value $(60 \%)$ was achieved by BTH against $F$. oxysporum on Giza 86 and $F$. moniliforme on Giza 90 while the least efficiency was observed by BTH seed treated against Rhizoctonia solani infection. Since $50 \mathrm{ppm}$ of BTH seed treatment caused 18.18 and $21.49 \%$ protection in cotton seedlings of cvs. Giza 86 and Giza 90, respectively. Using 100ppm of BTH gave cotton seedlings with 31.81 and $25.62 \%$ protection for Giza 86 and Giza 90, respectively.
\end{abstract}

\section{INTRODUCTION}

Seed- and soil-borne organisms, acting singly or in combination, produce the seedling disease complex of cotton. These organisms are found in all cotton-producing areas of Egypt. The disease occurs as pergermination decay of the seed, decay of the seedling on the way to the soil surface (preemergency damping-off) partial or complete girdling of the emerged seedling at or near the soil surface (sore shin or post-emergency damping-off) and seedling root rot (Watkins, 1981). Several of the fungi involved in seedling disease complex are also implicated in root rot of older plants. The pathogens most commonly involved in the disease complex are Rhizoctonia solani (ElAkkad, 1997 and El-Samawaty, 1990), Fusarium spp.(Aly et al., 1996 and ElSamawaty., 2004), Macrophomina phaseolina (Aly et al.,1998; Abdel-Latif et al., 2000 and Omar, 2005), Pythium spp. (Eisa,1983) and Sclerotium rolfsii (Khashaba,1972).

Upon infection with necrotizing pathogens, many plants develop an enhanced broad spectrum resistance to pathogens in the area of primary infection and in the distal, uninoculated organs (Sticher et al., 1997). This socalled systemic acquired resistance (SAR) requires the endogenous 
accumulation of salicylic acid (SA) (Dempsey et al., 1999) and can also be induced by exogenous application of $\mathrm{SA}$ or its synthetic analogs 2,6dichloroisonicotinic acid (Me'traux et al., 1991; Elad, 1992; Galal and Abdou, 1996 and Galal et al., 2001) and benzothiadiazole (BTH) (Friedrich et al., 1996; Ismail et al., 2006). SAR is associated with the activation of genes encoding pathogenesis-related (PR) proteins, some with antimicrobial activity (Van Loon and Van Strien, 1999), and with the ability to induce cellular defense responses more rapidly and to a greater degree than in noninduced plants (Mur et al., 1996). Thus, inducing systemic resistance in the host plant becomes a good method for minimizing disease incidence/severity with least cost and without environmental pollution (Elad, 1992 and Galal and Abdou, 1996 Galal et al., 2001). Over the past decade, a parsley cell culture/Phytophthora sojae cell wall elicitor model system has proven useful in studying cell priming and the resulting potentiation of cellular plant defense responses (Conrath et al., 2001): Preincubation with SA, 2,6dichloroisonicotinic acid, or BTH, in a strictly time-dependent process, primed parsley cells for stronger low-dose elicitation of various of cellular defense responses (Kohler, 2002).

Acibenzolar-S methyl (ABM), or benzothiadiazole $(B T H)$, has been released in Europe as BION (Syngenta Ltd., Basel, Switzerland) and in the United States as Actigard (Syngenta Crop Protection Inc., Greensboro, North Carolina). ABM has been reported to induce resistance in wheat against fungal pathogens (Görlach et al., 1996 and Morris et al., 1998), in bean against fungal infections (Siegrist et al., 1997.), and in tobacco and Arabidopsis spp. against fungal, bacterial, and viral infections (Cole, 1999 and Lawton et al., 1996). ABM complies with the definition of a systemic acquired resistance (SAR) inducers: it gives protection to the same spectrum of pathogens, causes the expression of the same molecular and biochemical markers (e.g., PR proteins) as biological inducers, and does not have direct antimicrobial activity (Kessmann et al., 1994). Resistance inducers are not necessarily a replacement for traditional fungicides and bactericides. Its use in conjunction with or alternated with these pesticides may lead to a reduction of the number of applications and perhaps dose rate (Lyon and Newton, 1999 and Ortega et al., 1998). It may also help to extend the durability of resistance in cultivars with genes for resistance to specific pathogen races (Romero et al., 1998).

The objective of this study was to determine the response of cotton seedlings to seed treatment by resistance elicitor BTH for controlling infection with various soil-borne fungi pathogenic to cotton.

\section{MATERIALS AND METHODS}

\section{Pathogens}

Seven fungi pathogenic to cotton seedlings, i.e. Fusarium solani; $F$. oxysporum, F. moniliforme, Sclerotium rolfsii, Macrophomina phaseolina, Pythium sp. and Rhizoctonia solani, were used in the present study. The fungi were isolated from seedlings infected with a variety of damping off symptoms or rooted rots of cotton plants that obtained from several cotton- 
producing areas in Egypt. Pure culture of the tested fungi were identified according to Gilman (1966) or Barnet and Hunter (1979) at cotton pathology lab., Plant Pathology Res. Inst., Agric. Res. Center, Giza.

\section{Seed treatment}

Seed of cotton cultivars Giza 86 and Giza 90 were treated with benzothiodiazole (BTH) at the rate of 50 and $100 \mathrm{ppm}$. Seeds of cotton were soaked in BTH concentrations for $12 \mathrm{~h}$, before planting in soils infested with the tested fungi.

\section{Effect of resistance elicitor BTH on cotton seed germination}

BTH was dissolved in deionized distilled water (DDW) at 50 and 100 ppm and DDW was served as control. Seeds of cotton cultivars Giza 86 and Giza 90 were delented using $1.0 \%$ sulfuric acid then washed thoroughly by DDW and blotted dried immediately before soaking in the test solution. Sterilized seeds were soaked in the test solutions for $12 \mathrm{hrs}$ before planting. Treated seeds were distributed onto sterilized filter papers saturated with sterilized distilled water in sterilized Petri plates at the rate of 10 seeds per plate. Seeded plates were incubated at $25^{\circ} \mathrm{C}$ for 10 days. Germination rate (\%) was measured as described by Strandberg and White (1989). Three plates were used per treatment and the experiment was repeated twice.

\section{Effect of resistance elicitor BTH on growth of the tested fungi}

BTH was prepared in $50 \mathrm{ml}$ of autoclaved distilled water, then added after cooling at room temperature to nutrient broth liquid medium before solidify to obtain the concentrations of 50 and $100 \mathrm{ppm}$, shacked gently, then poured into sterilized Petri dishes. Petri dishes were individually inoculated with one disk (5-mm diam.) of 10-day-old cultures of the tested fungi and incubated at $27^{\circ} \mathrm{C}$ for 14 days. Three replicates were used for each treatment and linear growth $(\mathrm{mm})$ was measured. For mycelial dry weight, concentrations of BTH compound (i.e. 50 and $100 \mathrm{ppm}$ ) were prepared in 50 $\mathrm{ml}$ of autoclaved nutrient broth liquid medium. Flasks were individually inoculated with one disk (5-mm diam.) of 10-day-old cultures of the tested fungi and incubated at $27^{\circ} \mathrm{C}$ for 14 days. Three flasks were used for each treatment. The mycelial fungi were filtered through filter paper Whitman No.1, dried at $70^{\circ} \mathrm{C}$ for $24 \mathrm{~h}$. then dry weight was recorded.

\section{Effect of BTH on susceptibility of cotton seedlings to the tested fungi}

Substrate for growth of the tested isolates of fungi was prepared in 500 $\mathrm{ml}$ glass bottles; each bottle contained $50 \mathrm{~g}$ of sorghum grains and $40 \mathrm{ml}$ of tap water. Contents of each bottle were autoclaved for 30 minutes. Isolate inoculum, taken from one - week-old culture on PDA, was aseptically introduced into the bottle and allowed to colonized sorghum for 3 weeks. Batches of autoclaved clay loam soil were infested separately with inoculum of each isolate of Rhizoctonia solani, Sclerotium rolfsii, Macrophomina phaseolina, Pythium sp., and 3 Fusarium spp. At the rates of 0.5, 5, 10, 30 and $50 \mathrm{~g} / \mathrm{kg}$ soil, respectively. Infested soil was dispensed in $10 \mathrm{~cm}$ diameter clay pots and these were planted with $10 \mathrm{BTH}$-treated seeds per pot. In the control treatment, seeds were treated with DDW and planted in infested soil. Pots were randomly distributed on a greenhouse bench. The experimental design was a randomized complete block with five replications. The prevailing temperature during study was $21.5 \pm 6.5$ (minimum) and $26.5 \pm 6.5$ (maximum). 
Infection (\%) plant height ( $\mathrm{cm} / \mathrm{plat})$, and dry weight (mg/plant) were recorded 45 days after planting.

Statistical analysis of the data

Analysis of variance (ANOVA) of the data was performed with MSTATC statistical package (A micro-computer program for the Design, Management and Analysis of Agronomic Research Experiments, Michigan State Univ., USA).Least significant difference (LSD) and standard error for means (SEM) were used to compare treatments means.

\section{RESULTS AND DISCUSSION}

\section{Effect of BTH on cotton seed germination}

Data summarized in Table (1) showed that the resistance elicitor BTH has no significant inhibitory effects on seed germination of cotton cultivars Giza 86 and Giza 90. Data are consistent with the effects resistance elicitors on sunflower seed germination (Ismail et al., 2006).

Table 1. Effect of (BTH) on seed germination of cultivars Giza 86 and Giza 90.

\begin{tabular}{ccc}
\hline Cotton cultivars & Conc. (ppm) & \% Germination rate \\
\hline \multirow{2}{*}{ Giza 86} & 0.0 & $88 \pm 3$ \\
& 50 & $85 \pm 6$ \\
\multirow{2}{*}{ Giza 90} & 100 & $80 \pm 5$ \\
& 0.0 & $86 \pm 4$ \\
& 50 & $84 \pm 6$ \\
& 100 & $82 \pm 4$
\end{tabular}

Data are means of 2 experiments (each experiment included 3 replicates (plates), \pm Standard error for means (SEM).

\section{Effect of BTH on growth of the tested fungi}

BTH has no significant antifungal effects on mycelial dry weight or linear growth (Table 2). These results were recorded previously (Ismail et al., 2006).

\section{Efficiency of BTH on susceptibility of cotton seedlings to the tested fungi}

Generally, BTH seed treatment (seed soaking) resulted in resistant cotton plants against infection by all pathogenic fungi tested, i.e. F. solani (Table 3), F. oxysporum (Table 4), F. moniliforme (Table 5), Sclerotium rolfsii (Table 6), Macrophomina phaseolina (Table 7), Pythium sp. (Table 8) and Rhizoctonia solani (Table 9). Efficiency of BTH to induce resistance in cotton plants varied with BTH concentration and fungi tested. Increasing BTH concentration enhanced resistance capacity of cotton cultivars. In addition, BTH seed treatment raised plant heights and weights of 45-day old plants.

Under F. solani infection, cotton cv. Giza 86 showed $35.7 \%$ protection upon seed soaking in 50ppm of BTH while cotton cv. Giza 90 gave $50 \%$ protection (Table 3). Increasing BTH concentration to 100ppm enhanced resistance of cotton plants cv. Giza 86 to $50 \%$ while resistance of cotton plants cv. Giza 90 remained unchanged (50\% protection). 
Table 2. Effect of BTH on mycelial dry weight and linear growth of tested fungi.

\begin{tabular}{|c|c|c|c|}
\hline Fungi & $\begin{array}{l}\text { Conc. } \\
\text { (ppm) }\end{array}$ & $\begin{array}{l}\text { Mycelial dry weight } \\
\text { (mg/50 ml liquid } \\
\text { medium) }\end{array}$ & $\begin{array}{c}\text { Linear } \\
\text { growth } \\
(\mathrm{mm})\end{array}$ \\
\hline Fusarium solani & $\begin{array}{c}0.0 \\
50 \\
100 \\
0.0\end{array}$ & $\begin{array}{l}246 \pm 4 \\
248 \pm 8 \\
242 \pm 6 \\
266 \pm 4\end{array}$ & $\begin{array}{l}83 \pm 2 \\
80 \pm 5 \\
82 \pm 3 \\
84 \pm 1\end{array}$ \\
\hline Fusarium oxysporum & $\begin{array}{c}50 \\
100 \\
\end{array}$ & $\begin{array}{l}258 \pm 8 \\
255 \pm 5 \\
\end{array}$ & $\begin{array}{l}83 \pm 2 \\
82 \pm 3\end{array}$ \\
\hline Fusarium moniliforme & $\begin{array}{l}0.0 \\
50 \\
100\end{array}$ & $\begin{array}{l}325 \pm 6 \\
320 \pm 5 \\
325 \pm 8 \\
\end{array}$ & $\begin{array}{l}82 \pm 3 \\
84 \pm 1 \\
83 \pm 2\end{array}$ \\
\hline Sclerotium rolfsii & $\begin{array}{c}0.0 \\
50 \\
100\end{array}$ & $\begin{array}{l}286 \pm 5 \\
282 \pm 8 \\
278 \pm 6\end{array}$ & $\begin{array}{l}85 \\
85 \\
85\end{array}$ \\
\hline $\begin{array}{l}\text { Macrophomina } \\
\text { phaseolina }\end{array}$ & $\begin{array}{c}0.0 \\
50 \\
100\end{array}$ & $\begin{array}{l}256 \pm 5 \\
258 \pm 8 \\
254 \pm 4 \\
\end{array}$ & $\begin{array}{c}85 \\
83 \pm 2 \\
82 \pm 3 \\
\end{array}$ \\
\hline Pythium sp. & $\begin{array}{c}0.0 \\
50 \\
100\end{array}$ & $\begin{array}{c}245 \pm 5 \\
246 \pm 48 \\
241 \pm 6\end{array}$ & $\begin{array}{l}83 \pm 1 \\
82 \pm 3 \\
84 \pm 2\end{array}$ \\
\hline Rhizoctonia solani & $\begin{array}{c}0.0 \\
50 \\
100\end{array}$ & $\begin{array}{l}336 \pm 5 \\
334 \pm 8 \\
328 \pm 4\end{array}$ & $\begin{array}{l}85 \\
85 \\
85\end{array}$ \\
\hline
\end{tabular}

Data are means of 2 experiments (each experiment included 3 replicates, (plates or flasks), \pm SEM.

Table 3. Effect of seed soaking in solutions of BTH on the infection of two cotton cultivars by Fusarium solani and on plant height (cm/plant) and dry weight ( $\mathrm{mg} / \mathrm{plant})$ at 45 days after planting.

\begin{tabular}{ccccccccc}
\hline $\begin{array}{c}\text { Conc. (ppm) } \\
\text { of BTH }\end{array}$ & $\begin{array}{c}\text { Infection } \\
(\%)\end{array}$ & \multicolumn{2}{c}{$\begin{array}{c}\text { Protection } \\
(\%)\end{array}$} & $\begin{array}{c}\text { Plant Height } \\
\text { cm/plant }\end{array}$ & $\begin{array}{c}\text { Dry weight } \\
\text { mg/plant }\end{array}$ \\
\cline { 2 - 9 } & Giza 86 Giza 90 & Giza 86 Giza 90 & Giza 86 & Giza 90 & Giza 86 Giza 90 \\
\hline 0.0 & 35 & 40 & 0.0 & 0.0 & 20.13 & 19.5 & 207.5 & 185.1 \\
50 & 22.5 & 20 & 35.7 & 50 & 21.88 & 21.58 & 208.6 & 202.2 \\
100 & 17.5 & 20 & 50 & 50 & 24.17 & 23.98 & 233.6 & 217.4 \\
\hline LSD for Conc. & 6.82 & 6.52 & & & 1.85 & 2.10 & 16.15 & 17.21 \\
\hline
\end{tabular}

Regarding $F$. oxysporum infection, cotton resistance increased by increasing BTH concentration for both cotton cultivars tested. Since 50ppm of BTH exhibited 40 and $23.1 \%$ protection in cotton seedlings of cvs. Giza 86 and Giza 90, respectively (Table 4). Using $100 \mathrm{ppm}$ of BTH induced resistance by 60 and $53.85 \%$ in cvs. Giza 86 and Giza 90, respectively.

As for F. moniliforme infection (Table 5), cotton plants of cv. Giza 90 were more responsive to BTH seed treatment than cv. Giza 86. However, plants of cv. Giza 90 showed the highest value of protection (60\%) at both 
BTH concentrations tested. Plants of cv. Giza 86 showed $36.25 \%$ and $50 \%$ protection upon seed treatment with 50 and 100 ppm of BTH, respectively.

Planting BTH-seed treated in Sclerotium rolfsii-infested soil resulted in resistant cotton seedlings. Protection of cotton plants increased with increasing BTH concentrations (Table 6). Using $50 \mathrm{ppm}$ of BTH induced resistance by 43.75 and $41.67 \%$ to cotton seedlings of cvs. Giza 86 and Giza 90 , respectively. Increasing BTH to $100 \mathrm{ppm}$ enhanced cotton protection to 56.25 and $58.33 \%$ for Giza 86 and Giza 90, respectively.

Table 4. Effect of seed soaking in solutions of BTH on the infection of two cotton cultivars by Fusarium oxysporum and on plant height $(\mathrm{cm})$ and dry weight $(\mathrm{mg})$ at 45 days after planting.

\begin{tabular}{ccccccccc}
\hline $\begin{array}{c}\text { Conc. (ppm) } \\
\text { of BTH }\end{array}$ & $\begin{array}{c}\text { Infection } \\
(\%)\end{array}$ & \multicolumn{2}{c}{$\begin{array}{c}\text { Protection } \\
(\%)\end{array}$} & $\begin{array}{c}\text { Plant Height } \\
\text { cm/plant }\end{array}$ & $\begin{array}{c}\text { Dry weight } \\
\text { mg/plant }\end{array}$ \\
\cline { 2 - 9 } & Giza 86 Giza 90 & Giza 86 & Giza 90 & Giza 86 & Giza 90 & Giza 86 Giza 90 \\
\hline 0.0 & 37.5 & 32.5 & 0.0 & 0.0 & 19.2 & 18.75 & 205.3 & 184.5 \\
50 & 22.5 & 25 & 40 & 23.1 & 21.33 & 19.35 & 223.1 & 187.5 \\
100 & 15 & 15 & 60 & 53.8 & 22.75 & 22.48 & 237.4 & 225.1 \\
\hline LSD for Conc. & 6.82 & 6.52 & & & 1.85 & 2.10 & 16.15 & 17.21 \\
\hline
\end{tabular}

Table 5. Effect of seed soaking in solutions of BTH on the infection of two cotton cultivars by Fusarium moniliforme and on plant height $(\mathrm{cm})$ and dry weight $(\mathrm{mg})$ at 45 days after planting.

\begin{tabular}{ccccccccc}
\hline $\begin{array}{c}\text { Conc. (ppm) } \\
\text { of BTH }\end{array}$ & $\begin{array}{c}\text { Infection } \\
\text { (\%) }\end{array}$ & \multicolumn{2}{c}{$\begin{array}{c}\text { Protection } \\
(\%)\end{array}$} & $\begin{array}{c}\text { Plant Height } \\
\text { cm/plant }\end{array}$ & $\begin{array}{c}\text { Dry weight } \\
\text { mg/plant }\end{array}$ \\
\cline { 2 - 9 } & Giza 86 Giza 90 Giza 86 Giza 90 & Giza 86 Giza 90 Giza 86 Giza 90 \\
\hline 0.0 & 40 & 37.5 & 0.0 & 0.0 & 20.58 & 17.82 & 207.5 & 185.1 \\
50 & 25.5 & 15 & 36.25 & 60 & 21.15 & 18.90 & 208.6 & 202.2 \\
100 & 20.0 & 15 & 50 & 60 & 22.30 & 22.0 & 233.6 & 217.4 \\
\hline LSD for Conc. & 6.82 & 6.52 & & & 1.85 & 2.10 & 16.15 & 17.21 \\
\hline
\end{tabular}

Table 6. Effect of seed soaking in solutions of BTH on the infection of two cotton cultivars by Sclerotium rolfsii and on plant height (cm) and dry weight ( $\mathrm{mg})$ at $\mathbf{4 5}$ days after planting.

\begin{tabular}{ccccccccc}
\hline $\begin{array}{c}\text { Conc. (ppm) } \\
\text { of BTH }\end{array}$ & \multicolumn{2}{c}{$\begin{array}{c}\text { Infection } \\
(\%)\end{array}$} & \multicolumn{2}{c}{$\begin{array}{c}\text { Protection } \\
(\%)\end{array}$} & \multicolumn{2}{c}{$\begin{array}{c}\text { Plant Height } \\
\text { cm/plant }\end{array}$} & \multicolumn{2}{c}{$\begin{array}{c}\text { Dry weight } \\
\text { mg/plant }\end{array}$} \\
\cline { 2 - 9 } & Giza 86 Giza 90 & Giza 86 & Giza 90 & Giza 86 Giza 90 Giza 86 Giza 90 \\
\hline 0.0 & 40 & 30 & 0.0 & 0.0 & 19.10 & 19.92 & 209.4 & 185.7 \\
50 & 22.5 & 17.5 & 43.75 & 41.67 & 20.13 & 20.33 & 211.6 & 212.4 \\
100 & 17.5 & 12.5 & 56.25 & 58.33 & 24.08 & 21.71 & 238.5 & 227.3 \\
\hline LSD for Conc. & 6.82 & 6.52 & & & 1.85 & 2.10 & 16.15 & 17.21 \\
\hline
\end{tabular}

Concerning Macrophomina phaseolina infection (Table 7), BTH seed treatment significantly increased resistance in cotton seedlings where cv. Giza 90 plants were more protected than plants of cv. Giza 86. Since 35.71 and $41.67 \%$ protection were expressed to cvs. Giza 86 and Giza 90, respectively, upon $50 \mathrm{ppm}$ of $\mathrm{BTH}$ treatment. Protection values were increased with increasing BTH concentration and 100ppm of BTH achieved 
41.43 and $58.33 \%$ protection to cvs. Giza 86 and Giza 90, respectively. AS for Pythium sp. Infection (Table 8), both concentration of BTH gave same protection for cotton plants of cv. Giza 90, while protection of cotton seedlings of cv. Giza 86 increased with increasing BTH concentration.

Table 7. Effect of seed soaking in solutions of BTH on the infection of two cotton cultivars by Macrophomina phaseolina and on plant height $(\mathrm{cm})$ and dry weight $(\mathrm{mg})$ at 45 days after planting.

\begin{tabular}{ccccccccc}
\hline $\begin{array}{c}\text { Conc. (ppm) } \\
\text { of BTH }\end{array}$ & $\begin{array}{c}\text { Infection } \\
(\%)\end{array}$ & \multicolumn{2}{c}{$\begin{array}{c}\text { Protection } \\
(\%)\end{array}$} & \multicolumn{2}{c}{$\begin{array}{c}\text { Plant Height } \\
\text { cm/plant }\end{array}$} & $\begin{array}{c}\text { Dry weight } \\
\text { mg/plant }\end{array}$ \\
\cline { 2 - 9 } & Giza 86 Giza 90 & Giza 86 Giza 90 & Giza 86 Giza 90 Giza 86 Giza 90 \\
\hline 0.0 & 35 & 30 & 0.0 & 0.0 & 19.55 & 19.92 & 171.7 & 185.7 \\
50 & 22.5 & 17.5 & 35.71 & 41.67 & 22.0 & 20.33 & 193.6 & 212.4 \\
100 & 20.5 & 12.5 & 41.43 & 58.33 & 23.70 & 21.70 & 207.8 & 227.3 \\
\hline LSD for Conc. & 6.82 & 6.52 & & & 1.85 & 2.10 & 16.15 & 17.21 \\
\hline
\end{tabular}

Table 8. Effect of seed soaking in solutions of BTH on the infection of two cotton cultivars by Pythium sp. and on plant height (cm) and dry weight $(\mathrm{mg})$ at $\mathbf{4 5}$ days after planting.

\begin{tabular}{ccccccccc}
\hline $\begin{array}{c}\text { Conc. (ppm) } \\
\text { of BTH }\end{array}$ & $\begin{array}{c}\text { Infection } \\
(\%)\end{array}$ & \multicolumn{2}{c}{$\begin{array}{c}\text { Protection } \\
(\%)\end{array}$} & $\begin{array}{c}\text { Plant Height } \\
\text { cm/plant }\end{array}$ & $\begin{array}{c}\text { Dry weight } \\
\text { mg/plant }\end{array}$ \\
\cline { 2 - 9 } & Giza 86 Giza 90 & Giza 86 Giza 90 Giza 86 Giza 90 & Giza 86 Giza 90 \\
\hline 0.0 & 42.50 & 37.50 & 0.0 & 0.0 & 20.18 & 18.63 & 167.4 & 176.5 \\
50 & 32.50 & 27.50 & 23.52 & 26.67 & 21.23 & 20.35 & 193.0 & 210.5 \\
100 & 27.50 & 27.50 & 35.29 & 26.67 & 24.23 & 24.0 & 256.6 & 231.5 \\
\hline LSD for Conc. & 6.82 & 6.52 & & & 1.85 & 2.10 & 16.15 & 17.21 \\
\hline
\end{tabular}

However, least protection values were observed by BTH seed treated when they were planted in Rhizoctonia solani-infested soil (Table 9). Fifty part per million of BTH seed treatment caused 18.18 and $21.49 \%$ protection in cotton plants of cvs. Giza 86 and Giza 90, respectively. Using 100ppm of BTH gave cotton seedlings with 31.81 and $25.62 \%$ protection for Giza 86 and Giza 90, respectively.

Systemic resistance in plants can be induced by exogenous application of different chemicals, for instance salicylic acid (SA), and functional analog of SA such as 2-6-dichloro iso nicotinic acid (INA) and benzo $(1,2,3)$ thiadiazole -7-carbothionic acid S-methyl ester (BTH) as reported previously (Elad, 1992; Kesmann et al., 1994; Galal and Abdou, 1996; Friedrich et al., 1996 and Ismail et al., 2006).

Over the last 2 decades research on systemic acquired resistance (SAR) or induced systemic resistance (ISR) using model system has improved our understanding of the molecular basis of induced resistance and promoted the development of the synthetic elicitors. The future use of SAR or ISR to control crop pests in conventional agriculture seems promising because they provide good tools to control disease without causing direct selective pressure on pathogen population (Vallad and Goodman, 2004 and Mandal et al., 2008). 
Table 9. Effect of seed soaking in solutions of BTH on the infection of two cotton cultivars by Rhizoctonia solani and on plant height (cm) and dry weight ( $\mathrm{mg}$ ) at $\mathbf{4 5}$ days after planting.

\begin{tabular}{ccccccccc}
\hline $\begin{array}{c}\text { Conc. } \\
\text { (ppm) of } \\
\text { BTH }\end{array}$ & $\begin{array}{c}\text { Infection } \\
(\%)\end{array}$ & \multicolumn{2}{c}{$\begin{array}{c}\text { Protection } \\
(\%)\end{array}$} & \multicolumn{2}{c}{$\begin{array}{c}\text { Plant Height } \\
\text { cm/plant }\end{array}$} & $\begin{array}{c}\text { Dry weight } \\
\text { mg/plant }\end{array}$ \\
\cline { 2 - 9 } & Giza 86 & Giza 90 & Giza 86 & Giza 90 & Giza 86 Giza 90 Giza 86 Giza 90 \\
\hline 0.0 & 55 & 60.5 & 0.0 & 0.0 & 18.6 & 18.32 & $\square \square \square$ & 213.2 \\
50 & 45 & 47.5 & 18.18 & 21.49 & 19.9 & 20.87 & 219.2 & 216.3 \\
100 & 37.5 & 45 & 31.81 & 25.62 & 21.7 & 22.67 & 224 & 234.2 \\
\hline LSD for Conc. & 6.82 & 6.52 & & & 1.85 & 2.10 & 16.15 & 17.21 \\
\hline
\end{tabular}

The application of resistance elicitors also seems to be environmentally benign relative to currently used pesticides. The obtained results and the previous studies on SAR suggest that using resistance elicitors could be an attractive approach for managing crop diseases in a sustainable manner within the scope of a conventional agriculture system.

\section{REFERENCES}

Abd El-latif, M.R., N.A. Hussien, A.A. Galal, and A. Armanious-Hanaa. 2000. Biocontrol of cotton damping off, root rot and wilt diseases. The $8^{\text {th }}$ Conf. Agric. Develop. Res., 20-22 Nov. 2000, Ain Shams, Cairo, Egypt. pp. 1451-1468.

Aly, A.A., E.M. Hussein, M.A. Mostafa, and A.I. Ismail. 1996. Distribution identification, and pathogenicity of Fusarium spp. Isolated from some Egyptian cotton. Menofiya J. Agric. Res. 21:819-836.

Aly, A.A., Salwa M. Abd El-Rehim, and M.R. Omar. 1998. Susceptibility of some Egyptian cotton cultivars to Macrophomina phaseolina and its deteriorative effects on fiber quality. Menofiya J. Agric. Res. 23:11571167.

Barnett, H.L. and B.B. Hunter. 1979. Illustrated Genera of Imperfect Fungi. $3^{\text {rd }}$ Ed. Burgess Publishing Company, Minnesota, 241p.

Cole, D.L. (1999). The efficacy of acibenzolar- S-methyl, an inducer of systemic acquired resistance, against bacterial and fungal diseases of tobacco. Crop Prot. 18:267-273.

Conrath, U., O.U. Thulke, V.A. Katz, S. Schwindling, and A. Kohler. 2001. Priming as a mechanism in induced systemic resistance of plants. Eur. J. Plant Pathol. 107:113-119

Dempsey, D.A., J. Shah, and D.F. Klessig. 1999. Salicylic acid and disease resistance in plants. Crit. Rev. Plant Sci. 18: 547-575

Eisa, H.A. 1983. Host-parasite relationship in cotton seedling damping-off complex in ARE. Ph.D. Thesis, Cairo Univ., Cairo 174p.

Elad, Y. 1992. The use of antioxidants (Free radical scavengers) to control gray mould (Botrytis cinerea) and white mould (Sclerotinia sclerotiourm) in various crops. Plant Pathol. 41: 417-426.

El-Akkad, S.A.F. 1997. Studies on anastomosis group of Rhizoctonia solani Ph.D. Thesis, Cairo Univ., Cairo, 143p. 
El-Samawaty, A.M. 1999. Studies on cotton root rot disease. M.Sc. Thesis, Fac. Agric., Assiut Univ., 105pp.

El-Samawaty, A.M.A. 2004. Pathological studies on the interaction between some Fusarium species and cotton plants. Ph.D. Thesis, Fac. Agric., Minia Univ., 117pp.

Friedrich, L., K. Lawton, W. Ruess, P. Masner, N. Specker, M. Gut-Rella, B. Meier, S. Dincher, T. Staub, S. Uknes et al. 1996. A benzothiadiazole derivative induces systemic acquired resistance in tobacco. Plant J. 10: 61-70

Galal, A.A. and E.S. Abdou. 1996. Antioxidants for the control of Fusarial diseases in cowpea. Egypt J. Phytopathol. 24:1-12.

Galal, A.A., N.A. Hussien, M.R. Abd El-Latif and A.H. Armanious-Hanaa. 2001. Control of cotton root rot and wilt by ascorbic acid, propylgallate, thiourea and benlate. Proc. Safe Alternatives of Pestic. For Pest Manag., Assiut Univ., 28-29 October 2001, Assiut, Egypt. pp. 59-69.

Gilman, D.C. 1966. A Manual of Soil Fungi . $2^{\text {nd }}$ Ed. The lowa State Univ. Press, lowa, 450p.

Görlach, J., S. Volrath, G. Knauf-Beiter, G. Hengy, U. Beckhove, K.H. Kogel, M. Oostendorp, T. Staub, E. Ward, H. Kessmann, and J. Ryals. 1996. Benzothiadiazole, a novel class of inducers of systemic acquired resistance, activates gene expression and disease resistance in wheat. Plant Cell 8:629-643.

Ismail, M.E., H.M. Abdalla, and A.A. Galal. 2006. Factors affecting induced resistance in sunflower plants against basal stem rot caused by Sclerotium rolfsii (Corticum rolfsii). Minia J. Agric. Res. \& Develop. 26: 405- 425

Kessmann, H., T. Stauv, C. Hofmann, T. Maetzke, and J. Herzog. 1994. Induction of systemic acquired disease resistance in plants by chemicals. Ann. Rev. Phytopathol. 32:439-459.

Khashaba, M.S. 1972. Pathological and anatomical studies on cotton roots infected with some soil fungi. M.Sc. Thesis, Ain Shams Univ., Cairo, $157 p$.

Kohler, A., S. Schwindling, and U. Conrath. 2002. Benzothiadiazole-induced priming for potentiated responses to pathogen infection, wounding, and infiltration of water into leaves requires the NPR!/NIM1 gene in arabidopsis. Plant Physiol. 128:1046-1056.

Lawton, K., L. Friedrich, M. Hunt, K. Weymann, T. Delaney, H. Kessmann, T. Staub, and J. Ryals. 1996. Benzothiadiazole induces disease resistance in Arabidopsis by activation of the systemic acquired resistance signal transduction pathway. Plant J. 10:71-82.

Lyon, G.D. and A.C. Newton (1999). Implementation of elicitor-mediated induced resistance in agriculture. Pages 299-318 In: Induce Plant Defenses Against Pathogens and Herbivores. Biochemistry, Ecology, and Agriculture. A. A. Agrawal, S. Tuzun, and E. Bent, eds. APS Press, St. Paul, MN. 
Mandal, B., S. Mandal, A.S. Csinos, N. Martinez, A.K. Culbreath, and H.R. Pappu. 2008. Biological and molecular analyses of the acibenzolar-Smethyl-induced systemic acquired resistance in flu-cured tobacco against tomato spotted wilt virus. Phytopathology 98: 196-204.

Me'traux, J.P., P. Ahl-Goy, T. Staub, J. Speich, A. Steinemann, J. Ryals, E. Ward. 1991. Induced resistance in cucumber in response to 2, 6dichloroisonicotinic acid and pathogens. In: Advances in Molecular Genetics of Plant-Microbe Interactions, H. Hennecke, D.P.S. Verma, eds, Vol 1. Kluwer Academic Publishers, Dordrecht, The Netherlands, pp 432-439

Morris, S.W.B., S. Vernooij, M. Titatarn, S. Starrett, C.C. Thomas, R. Wiltse, A. Frederiksen, A. Bhandhufalck, S. Hulbert and S. Uknes. 1998. Induced resistance responses in maize. Mol. Plant-Microbe Interact. 11:643-658.

Mur, L.A, G. Naylor, S.A.J. Warner, J.M. Sugars, R.F. White, and J. Draper. 1996. Salicylic acid potentiates defense gene expression in tissue exhibiting acquired resistance to pathogen attack. Plant J. 9: 559-571

Omar, M.R. 2005. Pathological and biochemical studies n Macrophomina phaseolina pathogenic on cotton. Ph.D. Thesis, Fac. Agric., Suez Canal Univ.,178pp.

Ortega, F., U. Steiner, and H.W. Dehne. 1998. Induced resistance: a tool for fungicide resistance management. Pestic. Sci. 53:193- 196.

Romero, A.M., C.S. Kousik, and D.F. Ritchie. 1998. Systemic acquired resistance reduces race changes to major resistance genes in pepper. Phytopathology: 88:S76 (Abstr.).

Siegrist, J., D. Glenewinkel, C. Kolle, and M. Schmidtke. 1997. Chemically induced resistance in green bean against bacterial and fungal pathogens. J. Plant Dis. Prot. 104:599- 610.

Sticher, L., B. Mauch-Mani, J.P. Me'traux. 1997. Systemic acquired resistance. Ann. Rev. Phytopathol. 35: 235-270.

Strandberg, J.O. and J.M. White. 1989. Response of carrot seeds to heat treatments. J. Amer. Soc. Hort. Sci. 114:766-769.

Vallad, G.E. and R.M. Goodman. 2004. Systemic acquired resistance and induced systemic resistance in conventional agriculture. Crop Sci. 44: 1920-1934.

Van Loon, L.C. and E.A. Van Strien. 1999. The families of pathogenesisrelated proteins, their activities, and comparative analysis of PR-1 type proteins. Physiol. Mol. Plant Pathol. 55: 85-97.

Watkins, G.M. 1981. Compendium of Cotton Disease. The American Phytopathological Society, St. Paul., Minnesota. 87p. 


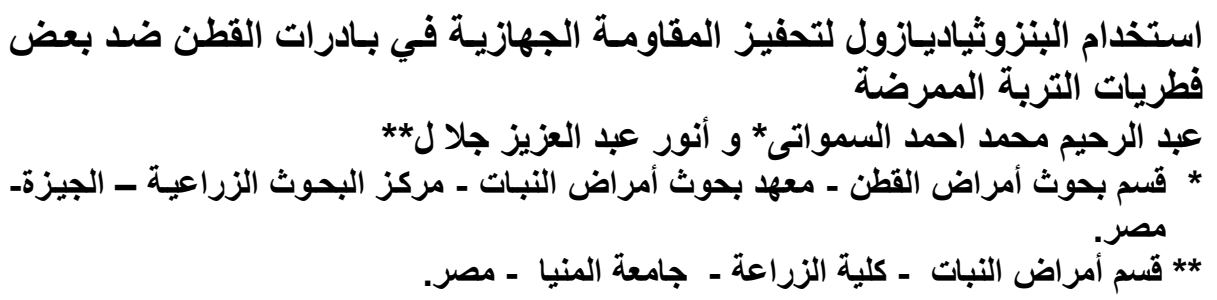

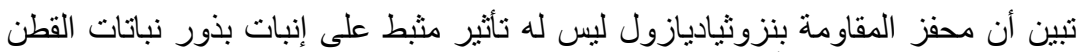

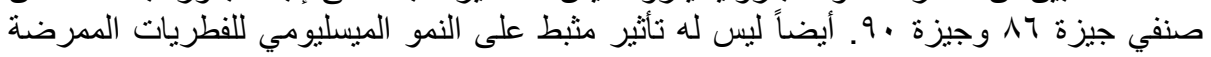
Fusarium solani; F. oxysporum, F. moniliforme, Sclerotium المختبرة لفئيرة rolfsii, Macrophomina phaseolina, Pythium sp. and Rhizoctonia solani,

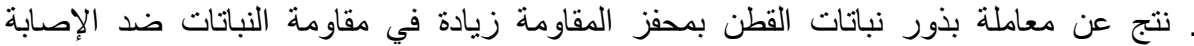

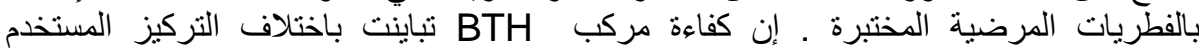

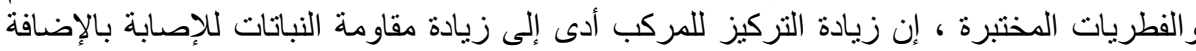

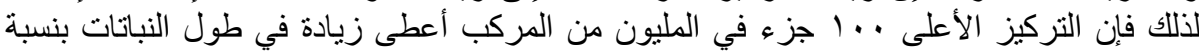

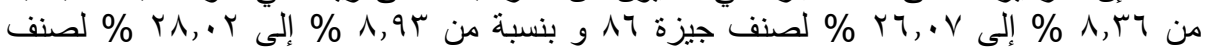

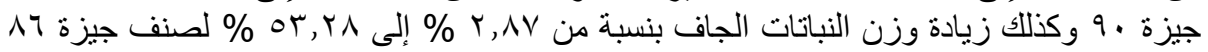

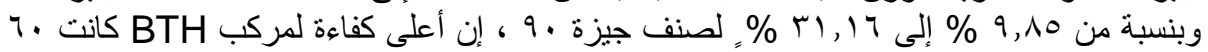

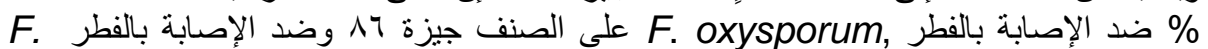
Roniliforme كلا الصنفين . 